
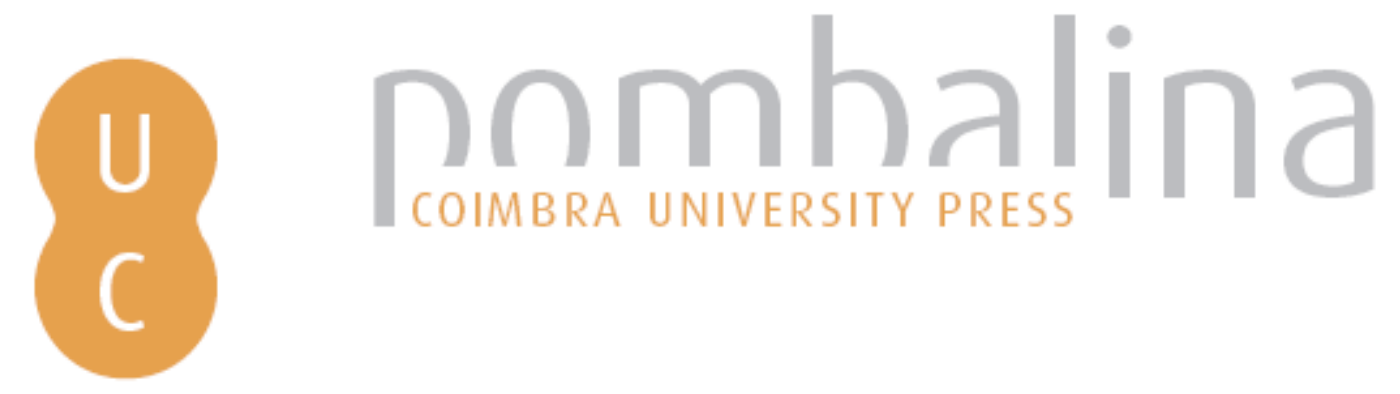

\title{
Alexandria's Revolutionary Role in North-South Navigation and Trade
}

Autor(es): $\quad$ El-Abbadi, Mostafa
Edições Afrontamento; CITCEM - Centro de Investigação Clássicos e Humanísticos; Alexandria University; Imprensa da Universidade de Coimbra
Publicado por: Transdisciplinar «Cultura, Espaço e Memória»; Centro de Estudos

$\begin{array}{ll}\text { URL } & \text { URI:http://hdl.handle.net/10316.2/36160 } \\ \text { persistente: } & \text { DOI:http://dx.doi.org/10.14195/978-989-26-0966-9_5 } \\ \text { DOI: } & \end{array}$

Accessed : $\quad$ 26-Apr-2023 09:46:41

A navegação consulta e descarregamento dos títulos inseridos nas Bibliotecas Digitais UC Digitalis, UC Pombalina e UC Impactum, pressupõem a aceitação plena e sem reservas dos Termos e Condições de Uso destas Bibliotecas Digitais, disponíveis em https://digitalis.uc.pt/pt-pt/termos.

Conforme exposto nos referidos Termos e Condições de Uso, o descarregamento de títulos de acesso restrito requer uma licença válida de autorização devendo o utilizador aceder ao(s) documento(s) a partir de um endereço de IP da instituição detentora da supramencionada licença.

Ao utilizador é apenas permitido o descarregamento para uso pessoal, pelo que o emprego do(s) título(s) descarregado(s) para outro fim, designadamente comercial, carece de autorização do respetivo autor ou editor da obra.

Na medida em que todas as obras da UC Digitalis se encontram protegidas pelo Código do Direito de Autor e Direitos Conexos e demais legislação aplicável, toda a cópia, parcial ou total, deste documento, nos casos em que é legalmente admitida, deverá conter ou fazer-se acompanhar por este aviso.

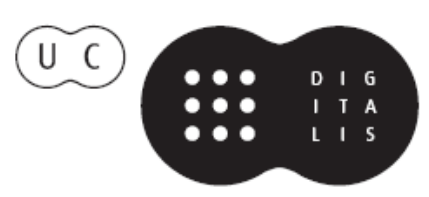




\title{
ALEXANDRIA'S REVOLUTIONARY ROLE IN NORTH-SOUTH NAVIGATION AND TRADE
}

\author{
MOSTAFA EL-ABBADI
}

University of Alexandria. Archaeological Society of Alexandria.

\begin{abstract}
The establishing of a direct connection in Antiquity between Egypt and India was a difficult and protracted process. Apart from unsubstantiated hypotheses, it went through four major stages: 1 - During the third and second millennia B.C. Egypt, directed its marine activities in the south to East Africa, which culminated in the expedition of Queen Hatshepsut to "Punt». 2 - The rise of Arabian kingdoms in south Arabia (Yemen) ca. 1000 B.C., and their caravan trade across the Arabian Peninsula. Due to their unique geographical location, they controlled transit trade between Egypt, India and East Africa. 3 - In the latter part of the 4th century B.C., the global enterprise of Alexander brought about drastic changes. The realization of India's fabulous commercial possibilities encouraged Alexandrian navigators to increase their profit from the exchange trade with India. 4 - The situation was further upset by the rise of Rome as the dominant power in the Mediterranean in the 2 nd century B.C. In response to the new changes and in order to further increase their profit, Alexandrian navigators realized that their only chance lay in by-passing the Arabian ports and in sailing directly across the ocean to India. This was achieved in 118-116 B.C. by discovering the Monsoon wind and their system. Gradually, Alexandrian navigators enjoyed an unrivaled dominance in the Red and Indian seas.
\end{abstract}

The establishing of a direct connection in Antiquity between Egypt and India was a difficult and protracted process. In this paper, I shall try to present a brief analysis of Egypt's historical experience. The earliest traceable relations between India and West Asia were first 
evident in the Gulf area and in Mesopotamia. Indian objects and Indian influences infiltrated from Mesopotamia by land through the hands of several intermediaries to other West-Asian countries including Egypt ${ }^{1}$.

On the other hand, we have records of a long chain of sea voyages and expeditions that set out in Antiquity from the Egyptian coast on the Red Sea to the Indian Ocean, yet the range and ultimate destination of those voyages have repeatedly been disputed. For example the German geographer Heinrich Quiring, once argued in 1952 that there existed in the past a persistent legend of a Gold Island in the East Indies and that expeditions were being sent out until early in the 16th century to find the magical golden island. He then suggests that in order to identify the Golden Island, we must shift our viewpoint back to ancient Egypt. After surveying Egyptian records of the journey to Punt, he suddenly attributes to Herodotus that those voyages set out from the Red Sea in long ships for the Indies. Quiring next asserts in the whole circumference of the Indian Ocean, Sumatra is the only island for which gold mining is demonstrable. He finally concludes that the Ramessides of the 12th century B.C. in search for gold, were chiefly responsible for those expeditions; he also adds that after the death of Ramses III (ca. 1166 B.C.) the Egyptian decline began to set in.... soon after, this relationship was broken, probably 1090 B.C. ${ }^{2}$.

More recently in 1975, another geographer, George Carter noted in a supporting paper «quiring shifts from Punt-in-Africa to Punt-in-the East-Indies. If Punt referred to the distant gold yielding land, it could have been both, or perhaps first one and then the other. The subject has long been debated $»^{3}$. We shall have occasion to consider the location of Punt later on.

The above hypothesis appears to be rather speculative and cannot be fully substantiated on available historical evidence as the direct sea voyage between Egypt and India during the third and second millennia B.C. was fraught with many uncertainties and unknown dangers, e.g.: a) unexplored sea routes b) total ignorance of the prevailing wind-system over the Indian Ocean, not to speak of the Pacific. The Monsoon winds can become too violent for sailing ships c) at times, the hazards of piracy constituted a serious menace to navigation. The overcoming of these obstacles was gradually achieved, one step after another. We can trace the following three major stages in the development of Egyptian activities and trade in the Indian Ocean:

1. In the first place, during the third and second millennia B.C., Pharaonic Egypt seems to have directed its commercial marine activities towards the western side of the Indian Ocean, namely East Africa; this activity appears to have started at the time of the Old

\footnotetext{
${ }^{1}$ RATNAGAR, 2001: 43-54; GADD, 1971: 132-3.

${ }^{2}$ QUIRING, 1952: 93-5.

${ }^{3}$ CARTER, 1975: 1-10.
} 
Kingdom around the middle of the third millennium B.C. and was maintained throughout ancient history. The climax of Egyptian activities in this direction was undoubtedly the great naval expedition of Queen Hatshepsut to Punt and several other East African locations (ca. 1500 B.C.). The description as illustrated by the text and scenes of the Deir-elBahari Temple in Luxor, impresses upon us the magnitude of the expedition and its wideranging field of operation ${ }^{4}$. An indication of the magnitude of such expeditions can be found in the great Papyrus Harris ${ }^{5}$, composed later on by Ramses IV, on his accession to the throne (1166 B.C.) in memory of his father Ramses III and his achievements. Among the great deeds of Ramses III is recorded a naval expedition to Punt composed of 10,000 men. In a sense, it was a military force capable of confronting any opposition, a formation such as Hatshepsut may have used for her expedition. Another point worth mentioning is the duration of the voyage. On two earlier occasions in the 6th Dynasty and again in the 12th Dynasty, we are told that the round journey to Punt, required three years ${ }^{6}$. This lengthy journey implies either a long sojourn at the destination or several stops on the way, a customary practice among merchants in Antiquity and the Middle Ages.

In view of the long-standing controversy around the location of Punt between Africa and Asia, I would like to consider a text that I believe should settle the question once and for all. It is a partly damaged inscription addressed to King Psamtek of the 7th century B.C. that records a startling climatic observation on conditions in the land of Punt that to my mind, has not been sufficiently taken note of. It reads as follows:

... a great marvel took place in thy reign, such as has not been seen or heard of; the heavens rained upon the mount of Punt, rain being scanty in the fields of the south... in this month the rainfall took place at a time when rain was out of season even in the north land, thy mother Neith of the temple of Sais came to thee to conduct to thee the Nile, giving life to your men ${ }^{7}$.

This is so far, the earliest known observation recording the Monsoon rain upon the mountains of Punt. The fact that this text explicitly states that the flooding of the Nile in summer was caused by rain on Punt, proves beyond any doubt that Punt could only be in East Africa; it could not be anywhere else in Asia, neither east nor west. In view of this evidence, I find it unacceptable, without conclusive evidence, to shift earlier Egyptian expeditions from East Africa to the Indies in the Pacific ${ }^{8}$. Yet it is conceivable that smaller naval units could have sailed east from the strait of Bab-el-Mandeb, hugging the coast as far as

\footnotetext{
${ }^{4}$ BREASTED, 1905: 187 (vol. II) ff.

${ }^{5}$ BREASTED, 1905: 15-412 (vol. IV).

${ }^{6}$ Cf. CARTER, 1975: 2.

${ }^{7}$ PETRIE, GRIFFITH, MURRAY, 1888: 107-8.

${ }^{8}$ As argued by QUIRING, 1952 and CARTER, 1975.
} 
India. Unfortunately we have no clear indication that it was a regular practice until the end of the second millennium B.C.

2. Secondly, around the year one thousand B.C. major changes took place in both the Eastern Mediterranean and the Indian Ocean. The Eastern Mediterranean suffered a commotion of several migrating peoples both by land and sea. In consequence, several older kingdoms fell and new ones emerged. Egypt had its share of suffering a succession of neighbouring foreign domination. In the western Indian Ocean, South Arabia, Yemen of today, emerged rather suddenly as a leading trading centre. This development was the direct result of discovering the peculiar faculty of the camel of being able to subsist without food and drink up to four days. Consequently, South Arabians were able to establish their caravan trade across the Arabian Peninsula and thereby became a chief participant in the valuable north-south trade between the Mediterranean and the Indian Ocean. Enhanced further by their unique geographical location in command of the straits of Bab-el-Mandeb, they were able to impose their own terms on the other principal participants in that trade: India, Egypt and East Africa. Thus no ship, Indian or Egyptian was allowed to sail north or south beyond the straits of Bab-el-Mandeb without the approval of the Arab authorities. As an alternative, the various parties were required to bring their respective wares and products to the Arabian ports and markets where they could conduct their exchange and business, to the profit of Arabia Felix (Eudaemon Arabia) as it came to be known. This arrangement however, allowed - perhaps for the first time - closer encounter and direct dealing between Indian and Egyptian merchants and sailors.

3. This situation continued for several centuries and each party maintained its role without any known violation until the 4th century B.C., when the global campaign of Alexander the Great, brought about drastic changes. For the first time, India became directly and better known to the Mediterranean people. As a result of the geographical explorations initiated by Alexander and maintained by his immediate successors, India in particular attracted the attention of Hellenistic scholars, most eminent among them were Eratosthenes and his colleagues of the Alexandria school ${ }^{9}$. With the combined better knowledge of the land of India and better realization of its fabulous commercial possibilities, Alexandrian sailors and merchants in Egypt tried to continuously increase their profit from the exchange trade with India in order to satisfy the ever-increasing demand in the Mediterranean market. Thus in the then prevailing conditions in the Indian Ocean, Alexandrian merchants controlled the sea-borne trade up and down the Red Sea while Nabataeans and South Arabians controlled the over-land caravan trade across the Arabian Desert whereas Indian and Arabian merchants strictly kept to themselves complete control of traf-

\footnotetext{
${ }^{9}$ Strb. 1.2.1.
} 
fic in the Indian Ocean. This delicate balance was maintained and jealously guarded till the middle of the 2nd century B.C. by the South Arabians who profited and prospered by being the main entrepôt centre for the north-south trade.

This commercial set up is very clearly reflected in two pertinent statements, the one by Diodorus Sicilus (mid-1st century B.C.) when he speaks of «The prosperous islands near Eudaemon Arabia which were visited by sailors from every port and especially from Potana, the city which Alexander founded on the river Indus» ${ }^{10}$. The other statement is of a later date (around A.D. 40) in the so-called Periplus of the Erythraean Sea by an unknown author. It reads as follows: «The port of Eudaemon Arabia (Aden) was once before a full fledged city, when vessels from India did not go to Egypt, and those of Egypt did not dare sail to places further on, but came only this far» ${ }^{11}$. Any attempts by Alexandrian ships to sail beyond the port of Eudaemon Arabia were strongly discouraged, if they did sail, it was by laboriously hugging the coast and in the words of the Periplus «sailing round the bays» ${ }^{12}$.

4. This situation however was upset by a drastic change in the balance of power in the Mediterranean basin. The prominent position of South Arabia in the Indian Ocean was more than counterbalanced by the unforeseen rise of Rome as a dominant power in the Mediterranean after her victory over Carthage in 202 B.C. ${ }^{13}$. It was then that Rome adopted a policy of expansion and supremacy in the Eastern Mediterranean, while the island of Rhodes had been enjoying a central role in trade and navigation, and had maintained close friendly relations with all trading centers in the region. Rome however, looked with disfavour upon the prosperity of independent Rhodes. Not wishing to resort to the use of force against that powerful distant island, Rome launched what can be called a policy of economic blockade, by inducing or coercing other countries to transfer their route and agencies from Rhodes to the nearby poor island of Delos. Under growing Roman pressure, Alexandrian merchants gradually moved their ware-houses and agencies in accordance with the wish of Rome. There is ample evidence from the 2nd century B.C. testifying to the close trade connection between Alexandria and Delos. Significant in this respect is a dedicatory inscription set up in Delos by «The chiefs of the union of Alexandrian merchants» ${ }^{14}$.

In the direction of the Red Sea and the Indian Ocean, there was another development. With the growing awareness in Rome of the possibilities of the north-south trade in incense, spices, aromatics, precious stones, gold, ivory, ebony, medical herbs and later on silk, Roman businessmen sought to invest more in this line of trade through Alexandria.

\footnotetext{
${ }^{10}$ D.S. 3.47.9.

${ }^{11}$ Periplus, 1989: 26 lines 26-32.

${ }^{12}$ Periplus, 1989: 57. Also see editor's introduction and comm (p. 71-2).

${ }^{13}$ For points discussed in this section in greater detail, see EL-ABBADI, 1993: 22-37.

${ }^{14}$ DURRBACH, 1922: 108 (127-116 B.C.).
} 
Consequently, more Roman capital was pumped into the Alexandrian market. Accumulating evidence substantiate this point.

A papyrus of the mid-2nd century B.C. reveals the formation in Alexandria of a multinational company for the importation of aromata from «the incense-bearing land» (Punt). The papyrus is a maritime loan contract in which the various parties ( 1 creditor, 1 banker, 5 debtors and 5 guarantors) belong to at least 7 different civic affiliations: Rome, Carthage, Messalia, Elea, Thesalonica and Macedonia. It is significant that the Roman, named Gnaeus was the banker through whose bank the transaction was made ${ }^{15}$.

Other inscriptions from Delos of the second half of the 2nd century B.C. indicate that Romans and Italians were already firmly established in Alexandria in no small numbers. In one example, a dedication was made by «Italians at Alexandria» (Alexandreae Italicei) ${ }^{16}$. In another, we find Roman ship-owners and merchants dedicating to Apollo and expressing their gratitude to King Ptolemy VIII and to a certain Lochos who was a high ranking official at the royal court in Alexandria «on the occasion of the King's recovery of his throne in Alexandria» ${ }^{17}$. The occasion referred to in the dedication was that the King was expelled from Alexandria during a civil war (132-127 B.C.) and was reinstated by the intervention of the Roman senate.

The presence of this class of Romans and Italians was not confined to Alexandria since we meet them traversing the whole of Egypt up to the island of Philae, near Aswan. A small group of Latin inscriptions attest to this fact; they are written by four Roman citizens, three of them wrote down the date of their visit according to the Roman calendar (August 26th, 116 B.C. $)^{18}$. The date 116 B.C. of these Latin inscriptions is of special interest because it coincides with an event of a global significance, namely the discovery of the Monsoon winds in the Indian Ocean by Alexandrian navigators. The story of the discovery was first recorded by Poseidonius (ca.130-51 B.C.) and was later on recorded by Strabo (36 B.C.-22 A.D.) ${ }^{19}$ We are told that a shipwrecked Indian sailor was found half dead by Egyptian coast guards of the Red Sea and brought to King Ptolemy VIII. To gain favour, the Indian sailor promised to guide any of the King's navigators on a direct sea voyage to India. The King immediately assigned an adventurous seaman in his service, Eudoxus of Cyzicus with the mission. Poseidonius mentions two direct journeys to India undertaken by Eudoxus, the first in 118 B.C. guided by the Indian sailor, it proved a success and Eudoxus brought back a cargo of aromatics and precious stones. The second, under the sole guidance of Eudoxus occurred in 116 B.C., when the King had just died and his wife Queen Cleopatra III was still reigning.

\footnotetext{
${ }^{15}$ PREISIGKE, 1913-22.

${ }^{16}$ DURRBACH, 1922: 107.

${ }^{17}$ DURRBACH, 1922: 105-106 (127 B.C.).

${ }^{18}$ ROCCATI, 1977a: 838-9; and Supplementum Graecum 28.1485. Also see D.S. 1.83.8-9.

${ }^{19}$ Strb. 2.3.4-5.
} 
Although Strabo disbelieved the entire story of Eudoxus, modern scholarship has accepted the historicity of the facts of Eudoxus' two voyages ${ }^{20}$. They fit in with the international situation at the time. The enormous increase in the demand for Oriental and Southern goods in the Mediterranean market whetted the appetite of Alexandrian merchants to increase their share in the north-south trade. They also realized that their only chance lay in bypassing the Arabian ports and in sailing off directly across the ocean to the rich Indian market. Such an undertaking could not be attained without the substantial and powerful support of the Romans who were more than ready for the opportunity. It was not surprising therefore that Ptolemy VIII and his wife, both friends of Rome, demonstrated personal zeal and involvement in the project. The expertise of an Indian pilot with a thorough knowledge of the secret of the Monsoon winds would therefore be very much in demand.

The discovery of the Monsoon winds and their use for navigation by Alexandrian sailors had a very marked effect on the Egyptian scene. Not long after Eudoxus a new important office was created for the first time in the Egyptian administration, that of «Commander of the Red and Indian Seas», probably under Ptolemy XII in the first half of the 1st century B.C. The creation of such an office implies that the utilization of the Monsoon led to a marked increase in the regular commercial transactions with India. The new office was needed to ensure the safety of navigation engaged in that trade. Also, the fact that Rome decided in 56 B.C. to send a permanent Roman force to Alexandria to ensure the safety of King Ptolemy XII against any uprising by the population, confirms the magnitude of Roman capital invested in that trade.

The importance that Rome attached to that line of trade is confirmed still further, even after Augustus conquered and made Egypt a Roman province in 30 B.C. Soon after, in 26 B.C. Augustus commissioned his prefect in Egypt, Aelius Gallus to invade south Arabia by land. This land onslaught brought about considerable damage to the Sabaeans as far south as the city of Ma'reb, but did not completely cripple the commercial activity of the Arabian ports on the ocean ${ }^{21}$. Not satisfied with this result, Augustus later on in A.D. 1, launched another devastating naval attack ${ }^{22}$, that resulted, in the words of the Periplus «in sacking the port of Eudaemon Arabia (Aden) which declined into a mere village after having been a full-fledged city (polis) $»^{23}$.

Now that the port of Eudaemon Arabia was out of action, Alexandrian navigators of the Roman period enjoyed unrivalled dominance in the Red and Indian seas, a fact that rendered Egypt the main link between India and the Mediterranean.

\footnotetext{
20 THIEL, 1966, passim; OTTO, BENGTON, 1938: 1-22.

${ }^{21}$ Str. 16.4.23-24.

22 Plin. Historia Naturalis, 4.32.160; 12.30.55.

${ }^{23}$ Periplus, 26; Commentaries: 160.
} 